\title{
Government Sector Re-alignment in Sri Lanka and the Role of Visionary Leadership \& Process Re-engineering
}

\author{
Harin Gunawardena ${ }^{1}$
}

SLJDA 2015 (5): 37-57

\begin{abstract}
This paper initially discusses the necessity for realigning the mission and operations of government agencies to meet the changing demands of the environment, highlighting the need for organisational transformation (OT). Thereafter the paper moves on to discuss e-government as a key enabler to facilitate government sector re-alignment (GSR), and discusses the concepts of change content and change implementation within the context of OT. Researchers have identified over $70 \%$ of such initiatives which have not been successful and at the same time other researchers have identified the lack of attention on change content. Therefore this paper identifies visionary leadership and Government Process Re-engineering (GPR) as a methodology for developing change content. The use of GPR as a methodology facilitates a shift from developing structure based change content towards process based change content - which would enable the organisation to view the required re-alignment from a more holistic perspective.
\end{abstract}

Key words : e-govermment, GPR, visionary leadership, change content, vision

\section{Introduction}

Globalisation and rapid growth in technology are demanding organisations to compete in continuously changing and complex environments (Michela, Carlotta, \& Andrea, 2012), where organisational leaders are called upon to guide their organisations to adapt to these changing environments, which requires both innovation (Porter, 1998; Lundvall, 1988; Nonaka \& Takeuchi, 1995; Teece et al. 1997) and organisational transformation (Hammer \& Champy, 1993; Gordon et al., 2000; Van de Ven \& Poole, 2005; Burnes, 2009). On the other hand both researchers and practitioners argue that around $70 \%$ of such Organisational Transformation (OT) initiatives have not been successful (Judge \& Douglas, 2009; McKinsey \& Company, 2008). As the organisational environments continue to change, the necessity to re-align the organisation is becoming even more important. Such a

1 The author is a leading BPR consultant for many government process re-engineering initiatives in Sri Lanka and a Director of Harmon Solutions (pvt) Ltd. and reading for his PhD at the PIM. The author could be contacted on harin.gunawardena@gmail.com 
necessity for organisational re-alignment highlights the need for OT and therefore understanding the reasons for the high rates of failure in relation to OT is becoming even more important. Based on the work of other researchers OT is defined as "a planned initiative, which is large in scale, involving multiple functional divisions and affect the core business and administrative processes of the organisation" (Weick \& Quinn, 1999; Hammer \& Champy, 1993; Fernandez \& Rainey, 2006).

Researchers have separately identified re-engineering to be an appropriate methodology for organisations that need to undertake radical change for re-aligning themselves with rapidly changing environments (Hammer \& Champy, 1993). In 2011, Gunawardena and Dharmasiri highlight the necessity for process re-engineering as a methodology for developing change content in the context of re-aligning government agencies, citing the speech made by the former Secretary to the President of Sri Lanka, Lalith Weeratunga, at the inauguration of the $\mathrm{CIO}$ (Chief Innovation Officers) training programme, where he stated "government sector re-engineering is needed in Sri Lanka in order to make the 'government sector relevant'" (Gunawardena \& Dharmasiri, 2011, p. 41) thus arguing process re-engineering as an appropriate strategy for re-aligning government sector organisations. In the context of OT, organisations need to assess the alignment of their "mission" as well as their "operations" (Gunawardena \& Dharmasiri, 2011). While the mission deals with "what is expected from the organisation?" which will be defined in more general terms as the "future perspective" of the organisation, "operations" deal with the question "how do organisations achieve their mission?". Therefore the success of an OT would depend on the appropriateness of the re-alignment of the "mission" or "future perspective" as well as the "operations". Based on this broad problem, the paper intends to focus on the specific research question "How can visionary leadership and process re-engineering enhance the success of Sri Lankan government sector OT?"

\section{Scope of the research}

Armenakis \& Bedeian (1999), based on the literature review conducted on OT, identify change content, change implementation and contextual issues as the factors influencing the success or failure of an OT. Subsequent empirical work of Huy (2001) and Cole et al (2006) argue that change content and change implementation are in fact the primary factors influencing OT outcomes. Change content is referred to as the substance of change or "the what" of change within the context of OT and includes elements such as strategy, structures, processes and people 
(Huy, 2001; Nadler \& Tushman, 1989; Pettigrew, 1987), highlighting the cognitive nature of change content. In contrast, change implementation is referred to by researchers as the process of implementing the change content within the organisation (Armenakis \& Bedeian, 1999), which is associated with the behavioural aspects of the change initiative. Other researchers have identified change content as an area that needs greater attention (Baum et al, 1998; Kantabutra, 2007, O'Connell, et al, 2011), since until now the greater emphasis of research has been on change implementation (Lee et al, 2013). Based on the arguments mentioned above, the scope of this paper will concentrate on understanding OT through the lens of change content.

\section{Literature review}

Within the literature review the author intends to initially discuss the concept of e-government. Thereafter the discussion will move on to the concepts of organisational transformation, change content, process reengineering and visionary leadership which are necessary for effective re-alignment of government agencies through e-government.

\section{e-Government}

As the need for government agencies to re-align their organisations was necessitated with the impact of globalisation and the rapid development of technology, it is imperative for organisations to better understand the role of technology in the context of their organisations. E-government is a concept that supports the introduction of technology within government, to which researchers have referred in different ways. However the consensus among the researchers is that there must be the introduction of information and communication technology (ICT) within the government institutions for e-government to exist. One such definition for e-government is "every governmental action that is based on the use of computer networks" (Montagna, 2005, p. 206). He argues that e-government could be as broad as a guiding vision for governments that includes the modernisation and reorganisation of government or specific initiatives such as e-Democracy, e-Voting, e-Assistance, e-Healthcare, etc. Other researchers have defined e-government from a narrow perspective as the "delivery of government information and services online through the Internet or other digital means" (West, 2004, p. 16). Another factor to which researchers refer in the context of e-government is its similarity to e-commerce (Montagna, 2005; West, 2004) thus highlighting the transactional nature of e-government. While acknowledging the similarity between e-government and e-commerce, Carter \& Bélanger 
(2005) highlight three major differences. Firstly, in e-commerce, the customers are chosen by the business, while in e-government, all those seeking the services should be provided the service, irrespective of their financial status, physical disabilities or accessibility to the technology. Secondly, he argues that the structure of businesses is more centralised than that of government agencies and therefore introduces a challenge during the development and implementation of new e-government services. The third and final difference identified by Carter \& Bélanger (2005) is accountability and they argue that government agencies are required to allocate resources to develop services that are beneficial to the public and not necessarily financially viable. For the purpose of this paper e-government is considered to be the development and implementation of the required information systems to provide government services to the public.

Wasantha Deshapriya, the former Director for Re-engineering government at ICTA (Information and Communication Technology Agency of Sri Lanka) in an introductory session of a CIO training programme in Kalutara in 2014, identified three strategies adopted by the Sri Lankan government in relation to introducing e-government. These three strategies he identified as (1) e-services, (2) automation and (3) reengineering. He argued when government agencies maintained accurate electronic databases and the information that was maintained had value to the public, developing e-services would an appropriate strategy for implementing e-government. Conversely, when government agencies did not have electronic databases but the organisational processes were well established and aligned with both organisational as well as citizens' requirements, he identified the appropriate e-government strategy as "automation". In the situation where the existing processes cannot deliver the required standard of services to the public, he identified reengineering as the suitable strategy for implementing e-government.

Any of the above e-government strategies will require a transformation within the government agency as well as the public perceptions receiving the services. It is now evident that the success of an e-government initiative, irrespective of the strategy adopted would be dependent on the ability of the specific government agency to transform the organisation. However the scope of OT will increase with the extent of the re-alignment required of that organisation. While the extent of OT in the case of e-services will be low, it will increase with automation and the highest extent of OT will be experienced with re-engineering. As e-government requires different degrees of OT needing to be initiated within government agencies, it is necessary to better understand the concept OT, which will be discussed in the following section. 


\section{Organisational transformation (OT)}

Weick \& Quinn (1999), after reviewing the literature in the domain of organisational change, identified two distinct categories of change which they classified as "episodic" and "continuous". They described episodic change as "infrequent, discontinuous, and intentional" and continuous change "ongoing, evolving, and cumulative" (Weick \& Quinn, 1999, pp. $365 \& 375)$ respectively. Orlikowski (1996) associated continuous change with change that is emergent, i.e., "...the realization of a new pattern of organising in the absence of explicit a priori intentions" (p.65). On the other hand Weick \& Quinn (1999) identified episodic change as an intentional and planned response to a divergence between the organisation and the environment in which it operates and therefore requires a strategic and operational re-alignment. Hammer \& Champy (1993) had previously articulated a similar view on episodic organisational change when they stated that organisations need to undertake fundamental and dramatic changes in their strategies and processes to survive and grow in rapidly changing environments.

The consensus among researchers on "organisational transformation" (OT) is that they are "... initiatives involving large-scale, planned, strategic, and administrative change" (Fernandez and Rainey, 2006, p.168). Building from the above literature, the current author defines OT as "a planned initiative, which is large in scale involving multiple functional divisions and affects the core business and administrative processes of the organisation".

The type of OT that is required in the context organisational re-alignment is the episodic change referred to by Weick \& Quinn (1999). Since episodic change or OT is a planned initiative it requires a phase of planning or developing change content and a different phase of implementing the change content. In the subsequent section the paper deals with Kenny's maturity model of strategy formulation which discusses the relationship between the change content development phase and the change implementation phase.

\section{Maturity model of strategy formulation}

Based on the work of De Wit and Meyer (1999), Kenny (2006) argues that strategic problems are "wicked", when they are complicated, interconnected, ambiguous and uncertain. He further argues that a constructivist approach, characterised by doing and reflecting on the experience, is a more appropriate form of learning when organisations are faced with "wicked" problems that require radical change and 
innovation. This is so, since the solution to a "wicked" problem is unknown on one hand and no expert exists with the required knowledge to suggest a solution on the other. Therefore the solution to "wicked" problems needs to be developed by those who are currently experiencing the problems within the organisation through experience and reflection. This leads to Kenny's (2006) argument that when organisations are faced with "wicked" problems, which most of the time are unknown at the beginning and seem to be unpredictable, it initially requires learning. This approach is opposite to the traditional rational approach of strategic planning, where solutions are derived through the analysis of past situations. When organisations are confronted with "wicked" problems, analysis based on the rational approach is unable to provide a holistic understanding. Kenny argues that as the understanding of the problem grows, the organisation is in a better position to develop a strategic response and argues that strategy formulation is a process based on learning. His argument is that such a strategic response based on learning through a constructivist approach can be considered to "mature" when the overall understanding of the situation increases.

During the initial stages of OT involving both radical change and innovation, the organisation is faced with uncertainty which would require a critical or third order learning approach (Kenny, 2006). Sterling (2010-11) refers to third order learning as transformative learning. In transformative learning, instead of viewing a situation through the current worldview, an understanding of the current worldview is developed (Sterling, 2010-11). Such an understanding of the worldview would provide the opportunity for transforming the worldview, which would in turn give rise to a new understanding of the problem that would lead to alternate solutions to "wicked" problems, which have not been seen so far. As understanding of the problem grows, Kenny (2006) argues that there comes a point where a significant level of learning has been reached and then it is possible to determine the appropriate strategic response. Kenny's (2006) maturity model of strategy formulation is shown in figure (1) below. This model clearly differentiates between the initial initiation phase of the OT initiative - where there is little understanding of the problem - that requires third order learning, the establishment phase associated with the creation of the prototype - which requires second order learning and the consolidation phase associated with the rolling out of the solution - which requires first order learning. 


\begin{tabular}{|l|ll|}
\hline \multicolumn{1}{|c|}{ Interpretive } & \multicolumn{1}{c|}{ Adaptive } & \multicolumn{1}{c|}{ Rational (Linear) } \\
\hline $\begin{array}{l}\text { Third Order Learning } \\
\text { Generative/Critical }\end{array}$ & $\begin{array}{l}\text { Second Order Learning } \\
\text { Adaptive/Practical }\end{array}$ & $\begin{array}{l}\text { First Order Learning } \\
\text { Incremental/Technical }\end{array}$ \\
\hline $\begin{array}{l}\text { High Uncertainty } \\
\text { (Poorly understood) }\end{array}$ & $\begin{array}{l}\text { Decision to } \\
\text { implement }\end{array}$ & $\begin{array}{l}\text { Low Uncertainty } \\
\text { (Well understood) }\end{array}$ \\
\hline Time & V & \\
\hline Initiation & $\begin{array}{l}\text { Implementation } \\
\text { (Establishment) }\end{array}$ & $\begin{array}{l}\text { Implementation } \\
\text { (Consolidation) }\end{array}$ \\
\hline
\end{tabular}

Figure (1): Kenny's maturity model of strategy formulation Source: Kenny (2006)

Kenny (2006), based on this model clearly argues that there is and should be a clear point of separation between the initiation stage which involves organisational learning and deciding on the strategic intent and the implementation stage. The current author argues that this point of separation is achieved with the creation of change content (a detailed representation of the future organisation in operation). This change content should be the input for the establishment phase. This paper concentrates on the creation of change content within the initiation phase and therefore the implementation phase is excluded from the scope of this paper, leading to the next area of discussion, change content.

\section{Change content}

Mintzberg \& Westley (1992) had previously developed an argument similar to that of Sterling (2010-11) when they identified that change could take place at the narrow "concrete level", which could be associated with improvements of efficiency and effectiveness of the current operations or at the broader "conceptual level", where the change is associated with a change in mindset, vision or culture which Sterling (2010-11) associated with transformational learning. Mintzberg and Westley argue that a conceptual level change could be achieved only when it is associated with a corresponding change in structures, processes and people and termed by researchers as "change content" (Huy, 2001; Nadler and Tushman, 1989; Pettigrew, 1987). 


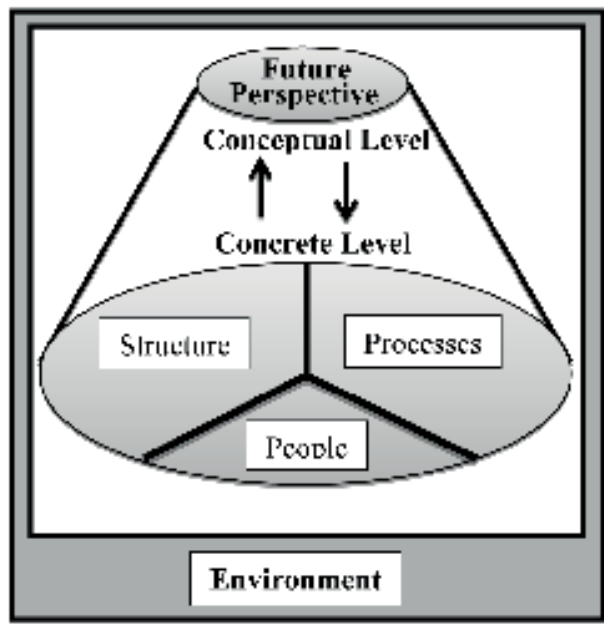

Figure (2.1): Representation of an organisation where the conceptual and concrete levels are aligned with the environment

Source: Author's Perspective
Figure 2.1 - represents the organisation as consisting of the future perspective (mission) and the operational elements of structures, processes and people aligned with the environment. The interaction between the conceptual level and the concrete level will ensure the alignment of the operations with the organisational mission. As environments change the operations will experience a corresponding evolutionary change. Over a period of time the change at the operational level will impact the conceptual level causing a misalignment between the organisation at both the conceptual and concrete levels and the environment, leading to the scenario described in figure 2.2.
Curreut State

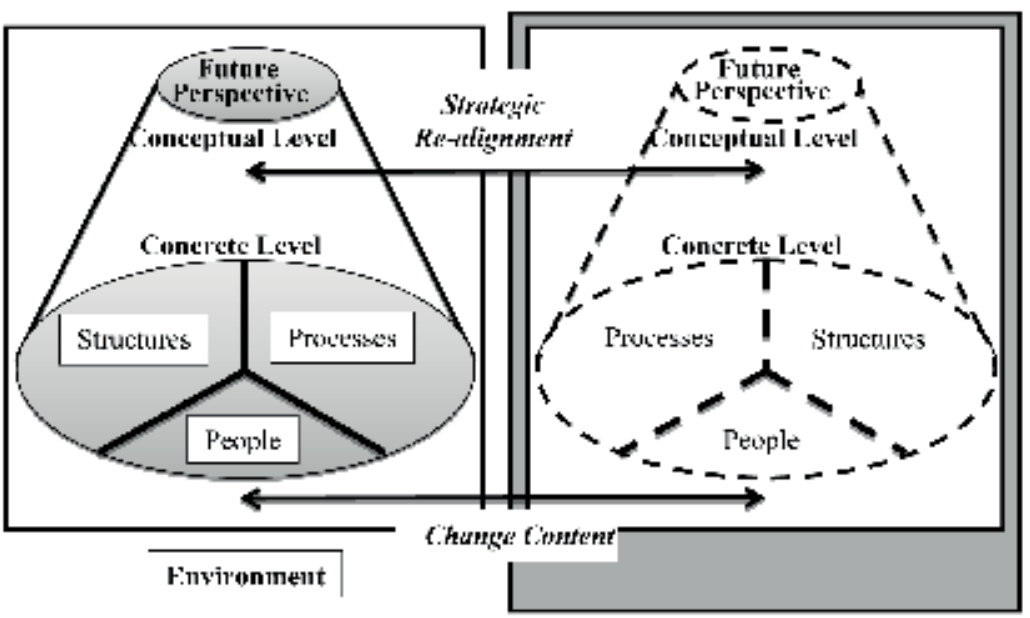

Figure (2.2): An organisation where the conceptual \& concrete levels are not aligned with its environment

Source: Author's Perspective 
Figure 2.2 above represents the scenario where the future perspective (mission) of the organisation as well as the operations of the organisation is not aligned with the environment. The "current state" depicts the misaligned scenario, and the "expected state" depicts the re-aligned scenario. The movement from the misaligned scenario to the re-aligned scenario calls for a shift in the future perspective which Mintzberg and Westley (1992) termed "strategic shift" and a shift at the concrete level which the current author has termed "change content" in line with other researchers (Huy, 2001; Nadler \& Tushman, 1989; Pettigrew, 1987).

Having established that change content represents the shift required at the operational level to re-align the organisation with the environment, the author now moves on to discuss how process re-engineering methodology facilitates the creation of change content.

\section{Process Re-engineering}

Hammer \& Champy (1993) defined business process re-engineering (BPR) as "the fundamental rethinking and radical redesign of business processes to achieve dramatic improvements in critical, contemporary measures of performance, such as cost, quality, service, and speed". As the pioneers of process re-engineering, they did not specify a framework to be followed but instead specified a set of principles that should be followed given below;

1. Organise work around outcomes, not tasks.

2. Identify all the processes in an organisation and prioritise them in order of redesign urgency.

3. Integrate information processing work into the real work that produces information.

4. Treat geographically dispersed resources as though they were centralised.

5. Link parallel activities in the workflow instead of just integrating their results.

6. Put the decision point where the work is performed, and build control into the process.

7. Capture information once and at the source.

In the absence of a specific framework for process re-engineering, researchers and practitioners have proposed their individual flavours of process re-engineering frameworks. Table (1) provides a cross section on these different frameworks and their corresponding sources. 


\section{Harin Gunawardena}

Table 1

Generic BPR Methodologies

\begin{tabular}{|c|c|c|c|c|c|}
\hline \multirow[b]{2}{*}{ Activity } & \multicolumn{5}{|c|}{ Methodology } \\
\hline & $\begin{array}{l}\text { Underdown } \\
\text { (1997) }\end{array}$ & $\begin{array}{l}\text { Harrison \& Pratt } \\
\text { (1993) }\end{array}$ & Furey (1993) & $\begin{array}{c}\text { Mayer \& } \\
\text { Dewitte } \\
(1998) \\
\end{array}$ & $\begin{array}{c}\text { Mangan- } \\
\text { elli \& Klein } \\
(1994)\end{array}$ \\
\hline 1 & $\begin{array}{l}\text { Develop } \\
\text { vision \& } \\
\text { strategy }\end{array}$ & $\begin{array}{l}\text { Determine Cus- } \\
\text { tomer Require- } \\
\text { ments \& Goals } \\
\text { for the Process }\end{array}$ & $\begin{array}{l}\text { Set Direc- } \\
\text { tion }\end{array}$ & $\begin{array}{l}\text { Motivating } \\
\text { Re-engi- } \\
\text { neering }\end{array}$ & Preparation \\
\hline 2 & $\begin{array}{l}\text { Create de- } \\
\text { sired culture }\end{array}$ & $\begin{array}{l}\text { Map and Mea- } \\
\text { sure the Existing } \\
\text { Process }\end{array}$ & $\begin{array}{l}\text { Baseline and } \\
\text { Benchmark }\end{array}$ & $\begin{array}{l}\text { Justifying } \\
\text { Re-engi- } \\
\text { neering }\end{array}$ & $\begin{array}{l}\text { Identifica- } \\
\text { tion }\end{array}$ \\
\hline 3 & $\begin{array}{l}\text { Integrate } \\
\text { \& Improve } \\
\text { enterprise }\end{array}$ & $\begin{array}{c}\text { Analyse and } \\
\text { Modify Existing } \\
\text { Process }\end{array}$ & $\begin{array}{l}\text { Create the } \\
\text { Vision }\end{array}$ & $\begin{array}{l}\text { Planning } \\
\text { Re-engi- } \\
\text { neering }\end{array}$ & Vision \\
\hline 4 & $\begin{array}{l}\text { Develop } \\
\text { technology } \\
\text { solutions }\end{array}$ & $\begin{array}{l}\text { Design a Re- } \\
\text { engineered } \\
\text { Process }\end{array}$ & $\begin{array}{l}\text { Launch } \\
\text { Problem } \\
\text { Solving } \\
\text { Projects }\end{array}$ & $\begin{array}{l}\text { Setting } \\
\text { up for Re- } \\
\text { engineering }\end{array}$ & $\begin{array}{l}\text { Technical } \\
\& \text { Social } \\
\text { design }\end{array}$ \\
\hline 5 & & $\begin{array}{l}\text { Implement the } \\
\text { Re-engineered } \\
\text { Process }\end{array}$ & $\begin{array}{l}\text { Design Im- } \\
\text { provements }\end{array}$ & $\begin{array}{l}\text { As Is De- } \\
\text { scription \& } \\
\text { Analysis }\end{array}$ & $\begin{array}{l}\text { Transforma- } \\
\text { tion }\end{array}$ \\
\hline 6 & & & $\begin{array}{l}\text { Implement } \\
\text { Change }\end{array}$ & $\begin{array}{c}\text { To-Be } \\
\text { Design and } \\
\text { Validation }\end{array}$ & \\
\hline 7 & & & $\begin{array}{c}\text { Embed } \\
\text { Continuous } \\
\text { Improve- } \\
\text { ment }\end{array}$ & $\begin{array}{l}\text { Implemen- } \\
\text { tation }\end{array}$ & \\
\hline
\end{tabular}

Source: (Gunawardena \& Dharmasiri, 2011, pp. 45-46) 
It is evident that those proposing BPR methodology have inferred process re-engineering to be a tool for both creating the change content as well as implementing the change. This view is supported by Davenport and Short (1990). However, a careful review of the definition of process reengineering proposed by Hammer \& Champy (1993) views BPR to be a methodology for designing change content within organisations. This misinterpretation of the definition of BPR is probably contributing to most of the BPR failures.

Based on Kenny's (2006) maturity model of strategy formulation, the current author argues that process re-engineering proposed by Hammer \& Champy (1993) was in fact a methodology for handling the initiation phase of an OT project that requires transformational or $3^{\text {rd }}$ order learning to address "wicked" problems faced by most government agencies and not a methodology for implementing change.

While the principles of BPR are applicable to government process reengineering (GPR), the definition below identified the deviation between GPR and BPR;

... the fundamental re-thinking and radical re-design of government processes to deliver dramatic improvements in quality of service, timely delivery at lower cost structures, while ensuring that the needs and aspirations of every citizen for national development, transparency, equality and safety are achieved. (Gunawardena \& Dharmasiri, 2011, p. 47)

The comparison of the above definition with that of Hammer \& Champy's (1993) definition of BPR bring to light the greater responsibility the government bears towards its citizens, in line with the arguments of Carter \& Bélanger (2005) in relation to e-government. Having discussed the concepts of BPR and GPR the author moves on to discuss visionary leadership theory.

\section{Visionary leadership theory}

Westley \& Mintzberg (1989) argue that the visioning process is initiated with an "idea" of the future organisation in the mind of the leader, which is then transformed into what they referred to as "vision", the term they used to represent the "idea" once it is shared among the followers. Furthermore, their theory states that this transformation is supported with vision articulation by the leader coupled with follower emotions and actions. They also highlight the necessity for dynamic interaction 
between the leader and followers during the process of creating these images of the future organisation. Having discussed the concepts relevant to this paper the author moves on to a discussion on how these concepts come together during the creation of change content when organisations are challenged to re-align themselves with the environment.

\section{Discussion}

Similar to most countries, Sri Lanka too initiated the e-government initiative around 2005. The main focus of the e-government initiative was to transform government agencies to become more responsive and citizen centric with the use of technology. The alignment of the "future perspective" of the organisation with the environment was reviewed. Figure 3 shows the future perspectives of multiple government agencies in Sri Lanka prior to the re-alignment and post re-alignment.

Figure 3: Future perspectives before and after the re-alignment

\begin{tabular}{|l|l|l|}
\hline \multicolumn{1}{|c|}{$\begin{array}{c}\text { Institution / Core } \\
\text { Process }\end{array}$} & \multicolumn{2}{c|}{ Future Perspective } \\
\cline { 2 - 3 } $\begin{array}{l}\text { Department of Pensions } \\
\text { - Effecting Gratuity and } \\
\text { Monthly Pension Payments }\end{array}$ & $\begin{array}{l}\text { The department waits } \\
\text { until all documentation is } \\
\text { received before process- } \\
\text { ing gratuity payments. } \\
\text { (Experience delays of over } \\
\text { 6 months). }\end{array}$ & $\begin{array}{l}\text { The department will ensure } \\
\text { the documents required } \\
\text { for processing the gratuity } \\
\text { payment is maintained on } \\
\text { an on-going basis to enable } \\
\text { the gratuity payment to be } \\
\text { made on the day of retire- } \\
\text { ment and monthly pension } \\
\text { payments from the follow- } \\
\text { ing month. }\end{array}$ \\
\hline $\begin{array}{l}\text { Department of Pensions - } \\
\text { Effecting Monthly W\&OP } \\
\text { Payments }\end{array}$ & $\begin{array}{l}\text { W\&OP eligibility is } \\
\text { determined only after } \\
\text { receiving information of } \\
\text { the pensioner's death and } \\
\text { other relevant documents. } \\
\text { (Delays encountered due to } \\
\text { disputes). }\end{array}$ & $\begin{array}{l}\text { Eligibility of W\&OP deter- } \\
\text { mined at the time the pen- } \\
\text { sion papers are processed } \\
\text { and stated on the Award } \\
\text { Letter. (Payments could be } \\
\text { made based on the death } \\
\text { certificate and bank infor- } \\
\text { mation only). }\end{array}$ \\
\hline $\begin{array}{l}\text { Department of Motor Traf- } \\
\text { fic - Registration of Motor } \\
\text { Vehicles }\end{array}$ & $\begin{array}{l}\text { Vehicles are only registered } \\
\text { when an importer sells the } \\
\text { vehicle. (Many vehicles in } \\
\text { the country remain unreg- } \\
\text { istered). }\end{array}$ & $\begin{array}{l}\text { Vehicles are registered } \\
\text { prior to its travelling on the } \\
\text { public road. }\end{array}$ \\
\hline
\end{tabular}




\begin{tabular}{|c|c|c|}
\hline \multirow{2}{*}{$\begin{array}{c}\text { Institution / Core } \\
\text { Process }\end{array}$} & \multicolumn{2}{|c|}{ Future Perspective } \\
\hline & Before Re-alignment & After Re-alignment \\
\hline $\begin{array}{l}\text { Registration of Persons } \\
\text { Dept. - Issue of National } \\
\text { ID Card }\end{array}$ & $\begin{array}{l}\text { An ID Card is issued when } \\
\text { the identity and residence } \\
\text { is certified by the GN with } \\
\text { a valid birth certificate. } \\
\text { (Those who do not have a } \\
\text { birth certificate or perma- } \\
\text { nent residence cannot be } \\
\text { registered). }\end{array}$ & $\begin{array}{l}\text { Every individual over the } \\
\text { age of } 18 \text { years is issued } \\
\text { an ID Card. (Ensuring all } \\
\text { individuals in the country } \\
\text { are registered). }\end{array}$ \\
\hline $\begin{array}{l}\text { Commissioner General of } \\
\text { Samurdhi Department - } \\
\text { Selection \& Issue of Samur- } \\
\text { dhi Benefits }\end{array}$ & $\begin{array}{l}\text { The selection of the Samur- } \\
\text { dhi beneficiary is based on } \\
\text { the information gathered } \\
\text { by the Samurdhi \& other } \\
\text { government officers. (Ac- } \\
\text { cusation that the ineligible } \\
\text { individuals are receiving } \\
\text { the benefit) }\end{array}$ & $\begin{array}{l}\text { The selection of the Samur- } \\
\text { dhi beneficiary is based on } \\
\text { the current financial status } \\
\text { of the individual assessed } \\
\text { by the community. (Those } \\
\text { making the accusation will } \\
\text { be involved in the selection } \\
\text { process). }\end{array}$ \\
\hline $\begin{array}{l}\text { Ministry of Lands - Issue } \\
\text { of Title Certificate }\end{array}$ & $\begin{array}{l}\text { All lands should be issued } \\
\text { with a title certificate. (Such } \\
\text { a process is convenient for } \\
\text { surveying - but lacks the } \\
\text { cooperation of the owner } \\
\text { - leading to inaccuracy, } \\
\text { disputes and a drop in } \\
\text { the confidence of the title } \\
\text { certificate). }\end{array}$ & $\begin{array}{l}\text { All lawful owners who } \\
\text { request should be issued } \\
\text { a title certificate. (Ensures } \\
\text { the support of the owner } \\
\text { is received when process- } \\
\text { ing the title certificate, thus } \\
\text { increasing the accuracy and } \\
\text { thereby the confidence of } \\
\text { the title certificate). }\end{array}$ \\
\hline $\begin{array}{l}\text { Local Government Author- } \\
\text { ity - Issue of Building } \\
\text { Permits }\end{array}$ & $\begin{array}{l}\text { Building Permit will be } \\
\text { issued based on the recom- } \\
\text { mendations of different } \\
\text { officers specialised in } \\
\text { different areas (e.g., PHI, } \\
\text { Development Officer, } \\
\text { Surveyor, Lawyer, etc.) re- } \\
\text { quiring multiple visits and } \\
\text { delays and inconvenience } \\
\text { to the owner. }\end{array}$ & $\begin{array}{l}\text { Building Permits will be } \\
\text { issued if they comply with } \\
\text { the existing planning regu- } \\
\text { lations without site visits. } \\
\text { (The permits could be is- } \\
\text { sued over the counter). }\end{array}$ \\
\hline $\begin{array}{l}\text { Ministry of Social Services } \\
\text { - Select Disadvantaged } \\
\text { Persons for Benefits }\end{array}$ & $\begin{array}{l}\text { The disadvantaged } \\
\text { individuals are selected } \\
\text { for a benefit based on the } \\
\text { application submitted by } \\
\text { the individual. (The indi- } \\
\text { vidual would apply only } \\
\text { for benefits of which he/ } \\
\text { she is aware.). }\end{array}$ & $\begin{array}{l}\text { Social Service Officers to } \\
\text { inform all forms of benefits } \\
\text { to the disadvantaged indi- } \\
\text { vidual. (The individual will } \\
\text { have the opportunity to re- } \\
\text { ceive all benefits provided } \\
\text { by the system). }\end{array}$ \\
\hline
\end{tabular}

Source: Current Author 
The information in figure (3) highlights the reactive nature of the future perspective prior to re-alignment and the responsive nature of the future perspective after the re-alignment. It was interesting that the re-aligned future perspective though different from the existing future perspective in all of the above cases is in-line with the stated "mission" of the specific government agency and therefore did not have to be generated anew. When leaders of these institutions were questioned as to why they are not carrying out the original mission of the agency, the common response was to explain the reasons for the agency being unable to achieve the original mission, based on current operations and environmental constraints. This empirical evidence proves the theoretical position argued in this paper that with the evolution of time, the concrete level operations change to accommodate environmental changes in an unplanned manner. Once the operations have changed they seem to influence the future perspective of the government agency, leading to the agency unwittingly moving away from their original "mission". As observed in most of these institutions the environment did not demand a shift in the future perspective but an undesired change of the future perspective had taken place, based on the unplanned changes experienced at the concrete level. This phenomenon provides evidence of the fact that while the conceptual level influences the concrete level, the concrete level in turn influences the conceptual level and agencies pursing a future perspective not aligned with the environment will eventually make itself redundant (Gunawardena \& Dharmasiri, 2011).

Based on this argument it is appropriate to posit that a re-alignment of the future perspective of the organisation at the conceptual level will necessarily require a shift in operations and the description of such a shift in the operations is represented by the "change content" (refer figure 2.2). This argument of the current author is supported by Mintzberg \& Westley (1992) who argue that a change at the conceptual level necessitates a change at the concrete level of the organisation represented figure 4 .

Figure 4: Relationship between future perspective and change content

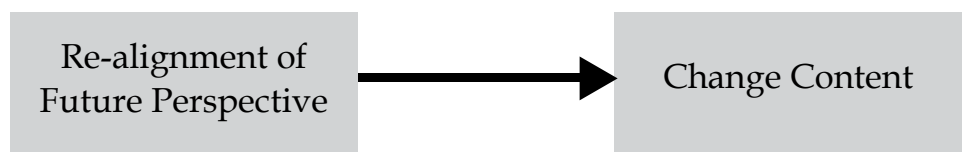

Source: Current Author 
Prior to initiating an OT initiative based on the GPR methodology, most of these government agencies had undertaken different types of change initiatives. Figure (5) below discusses the types of changes each organisation was pursing at the time the process re-engineering was initiated in each of these organisations.

Figure 5: Changes being persued when initiating GPR

\begin{tabular}{|c|c|}
\hline Institution/Core Process & Changes undertaken \\
\hline $\begin{array}{l}\text { Department of Pensions - Finalising } \\
\text { Gratuity and Monthly Pension } \\
\text { Payments }\end{array}$ & $\begin{array}{l}\text { - Introduce pension officers to each Divi- } \\
\text { sional Secretariat Division. } \\
\text { - Establish new units to handle special } \\
\text { cases. } \\
\text { - Establish a special unit to check pen- } \\
\text { sion applications and inform the errors } \\
\text { (approx. 70\% rejections). }\end{array}$ \\
\hline $\begin{array}{l}\text { Department of Pensions - Finalising } \\
\text { Monthly W\&OP Payments }\end{array}$ & $\begin{array}{l}\text { Introduce pension officers to each Divi- } \\
\text { sional Secretariat (DS) Division. } \\
\text { - Transfer the Pension File to the DS } \\
\text { Division. }\end{array}$ \\
\hline $\begin{array}{l}\text { Department of Motor Traffic - Registra- } \\
\text { tion of Motor Vehicles }\end{array}$ & $\begin{array}{l}\text { - Create a one day service unit. } \\
\text { - Streamline the office layout. } \\
\text { - Introduce application collection coun- } \\
\text { ters. }\end{array}$ \\
\hline $\begin{array}{l}\text { Registration of Persons Dept. - Issue of } \\
\text { National ID Card }\end{array}$ & $\begin{array}{l}\text { - Improve the security of the card. } \\
\text { - Create a one day service unit. } \\
\text { Introduce computers to type the infor- } \\
\text { mation instead of writing. }\end{array}$ \\
\hline $\begin{array}{l}\text { Commissioner General of Samurdhi De- } \\
\text { partment - Selection \& Issue of Samurdhi } \\
\text { Benefits }\end{array}$ & $\begin{array}{l}\text { - Introduce Samurdhi officers to each } \\
\text { Divisional Secretariat Division. } \\
\text { - Setup village committees to support the } \\
\text { selection of beneficiaries. } \\
\text { - Improve the security of the stamps. }\end{array}$ \\
\hline $\begin{array}{l}\text { Ministry of Lands - Issue of Title Certifi- } \\
\text { cate (TC) }\end{array}$ & $\begin{array}{l}\text { - Introduce incentive schemes. } \\
\text { - Modify the Act to make the TC compulsory. } \\
\text { - Establish separate offices in each area } \\
\text { and for each organisation involved. } \\
\text { - Introduce computers to print the TC. }\end{array}$ \\
\hline $\begin{array}{l}\text { Local Government Authority - Issue of } \\
\text { Building Permits }\end{array}$ & $\begin{array}{l}\text { Increase the resources available to visit } \\
\text { the building site. } \\
\text { - Increase the frequency of the Planning } \\
\text { Committee meetings. } \\
\text { - Separate the applications to areas. }\end{array}$ \\
\hline $\begin{array}{l}\text { Ministry of Social Services - Select Disad- } \\
\text { vantaged Persons for Benefits }\end{array}$ & $\begin{array}{l}\text { - Set up village committees. } \\
\text { - Introduce Social Service officers to each } \\
\text { Divisional Secretariat Division. } \\
\text { - Allocate the benefits to each DS Divi- } \\
\text { sion. } \\
\text { - Obtain the recommendation of the } \\
\text { Divisional Secretary on the selection. }\end{array}$ \\
\hline
\end{tabular}


The information in Figure 5 highlights the fact that most of the changes that were being pursued were structure based changes (e.g., a new person or unit is created to resolve the problem). Of course when there is a structural change there will be a corresponding change in the process and people. However, the changes being pursued were not having the desired benefit within those organisations. Further Nadler and Tushman (1989, p.198) argue that effective change content should include "... a fully developed description of the desired future state" of the organisation. None of the above mentioned structural changes provides such a "fully developed description of the future state". From the time Fredrick Taylor introduced scientific management, the concept of structure based changes have been practiced. When problems were not "wicked" such structure based changes may have been sufficient to address the organisational problems. However to address today's "wicked" problems, organisations would require a more holistic approach to change. Such a holistic view of the organisation can be created only when the organisation is viewed from a process perspective. In line with these arguments Levin (2000) argues that such a description of the future organisation would enable the followers to understand and visualise the future organisation in such detail that it produces a type of virtual experience of the end state.

GPR methodology discussed by Gunawardena \& Dharmasiri (2011) seems to provide the opportunity for government agencies to view their organisations from a process perspective and to develop the story of the future organisation. The current author's experience in adopting this GPR methodology has enabled the creation of change content, in the form of a story of the future organisation that is aligned to the needs of the environment. One specific step (Gunawardena \& Dharmasiri, 2011) in this methodology is to align the future perspective with top management aspirations. In order to achieve this step within the methodology it is necessary for individuals leading government agencies to create effective perspectives of the future organisation in their minds. Further, the methodology advocates the involvement of staff at all levels. The experience of the current author suggests that when leaders actively support such initiatives, staff actively participate and contribute in positive ways to develop the change content of the future organisation.

Westley \& Mintzberg's (1989) visionary leadership theory supports the argument that change takes place when the leader has an "idea" of the future organisation and is capable of articulating this idea to followers and the followers are willing contribute positively towards creating the future organisation. This argumenent is also supported by Hammer \& Champy (1993) who argue that it is only when employees are given a clean sheet that they are capable of creating the new organisation that 
will meet the various needs of the environment. Figure 6 brings together the factors influencng the re-designing of the processes and therefore the change content.

Figure 6: Factors influencing the re-designing of the processes

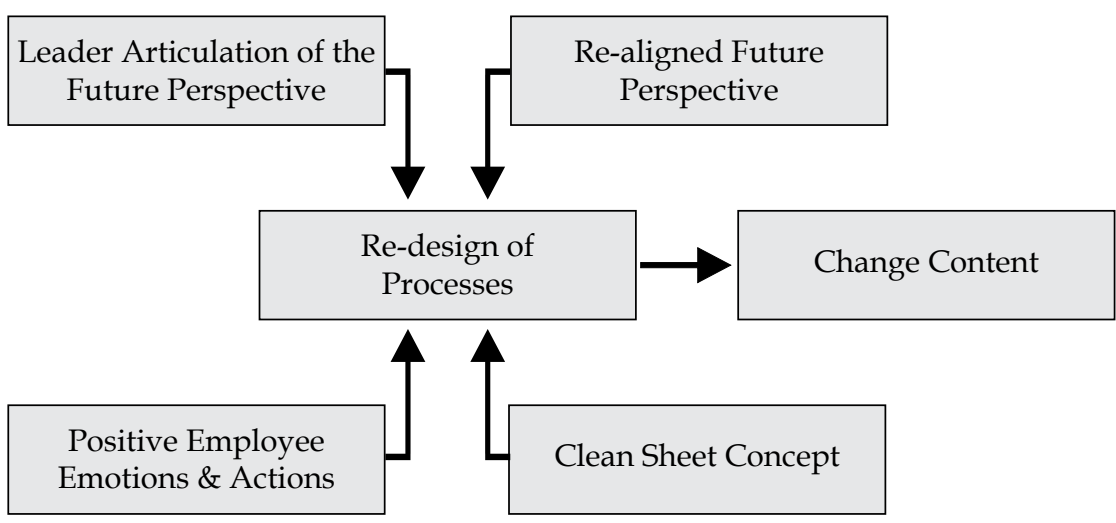

Source: Current Author

Based on the experience of the current author in undertaking GPR in multiple government agencies in Sri Lanka, leaders and followers, though capable, are reluctant to participate in designing the future processes of the organisation. The following concept indicator model represented in figure 7 would provide a theoretical framework for understanding the reluctance of leaders and followers to participate in creating change content for their organisations.

Figure 7: A conceptual indicator model for creating of change content

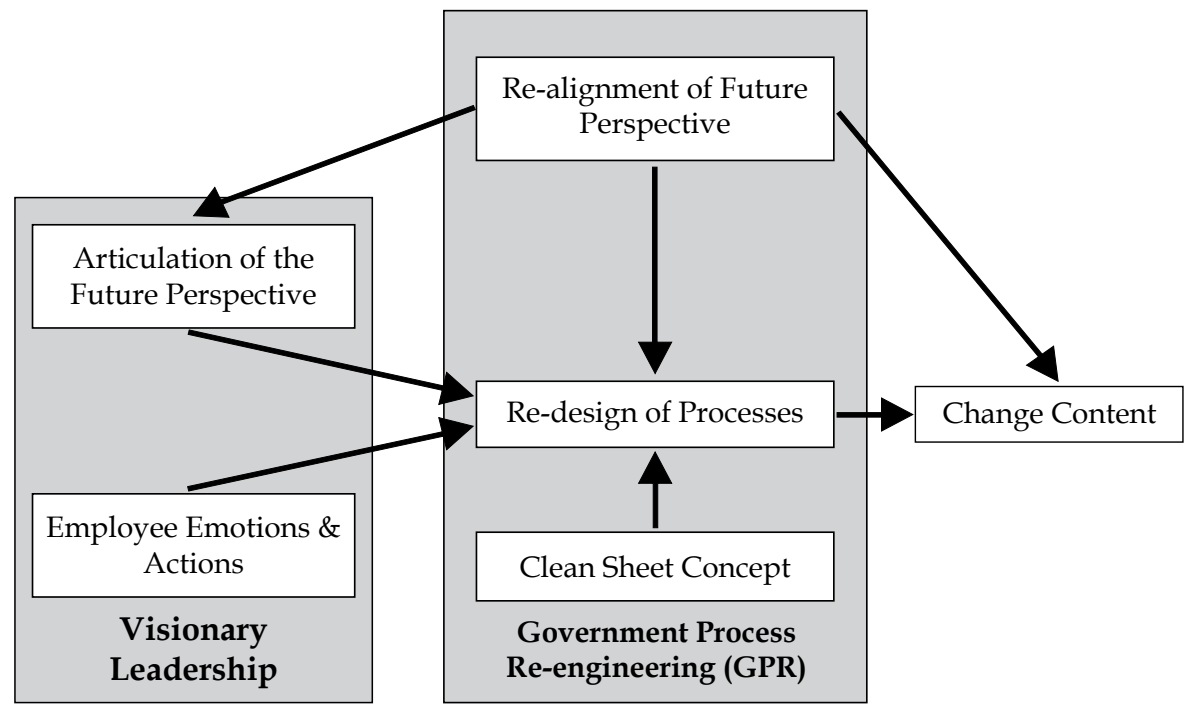

Source: Current Author 
Gunawardena \& Dharmasiri (2011) in their paper proposed a GPR methodology for redesigning the processes of government agencies adopting the "clean sheet" concept as well as creating a future perspective for the agency re-aligned with the environment. In this paper the antecedent for re-designing the processes is identified as visionary leadership.

In summarising this thesis it could be argued that change content is directly influenced by the re-alignment of the future perspective and the re-designed processes of the organisation. The re-designing the processes are in turn influenced by the extent to which the organisation is led by a visionary leader who is capable of effectively articulating the future perspective and generating the environment that would permit the employees to generate the required emotions to act in ways that would contribute towards the re-designing the processes. Strategically starting from a clean sheet will support the employees in creating a new organisation re-aligned with the environment.

\section{Conclusion}

This paper initially argues that GPR as a methodology supports capturing the cognitive and affective aspects in re-aligning an organisation and represented as change content. However, GPR as a methodology does not support the implementation of change within the organisation. This argument highlights the necessity and importance of GPR in the context of OT to develop change content, which is a primary area of focus in determining the success of an OT initiative. A GPR methodology as proposed by Gunawardena \& Dharmasiri (2011) could be adopted to achieve this objective.

Although visionary leadership has been discussed in general terms in relation to organisational change, no direct studies have highlighted the importance of visionary leadership in the context of e-government. This paper highlights the importance of visionary leadership in the context creating change content. Therefore government agencies interested in re-aligning their organisations through e-government and OT should begin to concentrate on the leadership capabilities within the selected government agencies prior to initiating such projects. The paper has also highlighted the importance of employee emotions and actions within a re-alignment initiative, an area that is rarely discussed in the government sector. 
In conclusion this paper argues that "visionary leadership" and "government process re-engineering" will positively impact the creation of change content, through the re-designing of processes, which has been already identified as being critical in OT required for e-government initiatives for re-aligning government agencies in Sri Lanka.

\section{Future research}

This paper is structured as a conceptual paper to better understand the factors that may influence the creation of change content, in the context of OT, e-government and re-aligning of government agencies, based on theory and the author's experience as a facilitator for creating such change content using the GPR methodology described in Gunawardena \& Dharmasiri (2011). Therefore it will be necessary to empirically validate the concept indicator model proposed in this paper.

\section{References}

Armenakis, A. A., \& Bedeian, A. G. (1999). Organizational change: A review of theory and research in the 1990s. Journal of management, 25(3), 293-315.

Baum, J. R., Locke, E. A., \& Kirkpatrick, S. A. (1998). A longitudinal study of the relation of vision and vision communication to venture growth in entrepreneurial firms. Journal of Applied Psychology, 83(1), 43-62.

Burnes, B. (2009). Managing Change (5th ed.). London: FT/Prentice Hall.

Burnes, B., \& Jackson, P. (2011). Success and Failure In Organizational Change: An Exploration of the Role of Values. Journal of Change Management, 11(2), 133 - 162.

Carter, L., \& Bélanger, F. (2005). The utilization of e-government services: citizen trust, innovation and acceptance factors. Info Systems Journal, 15, 5-25.

Cole, M. S., Harris, S. G., \& Bernerth, J. B. (2006). Exploring the implications of vision, appropriateness, and execution of organizational change. Leadership $\mathcal{E}$ Organization Development Journal, 27(5), 352-367.

Davenport, T. H., \& Short, J. E. (1990, July 15). The New Industrial Engineering: Information Technology and Business Process Redesign. Sloan Management Review.

Fernandez, S., \& Rainey, H. G. (2006, March). Managing Successful Organizational Change in Public Sector. Public Administration Review, 168 -176.

Gordon, S. S., Stewart, W. H., Sweo, R., \& Luker, W. A. (2000). Convergence versus strategic reorientation: The antecedents of fast-paced organizational change. Journal of Management, 26(5), 911-945.

Gunawardena, H., \& Dharmasiri, A. S. (2011). Organizational Reform in the Sri Lankan Public Sector: Developing a Process Re-engineering Framework. Sri Lanka Journal of Management, 16(3\&4), 41-61. 


\section{Harin Gunawardena}

Hammer, M., \& Champy, J. (1993). Re-engineering the Corporation: A Manifesto for Business Revolution. New York: Harper Collins Publication.

Huy, Q. N. (2001). Time, temporal capability, and planned change. Academy of management Review, 26(4), 601-623.

Judge, W., \& Douglas, T. (2009). Organizational change capacity: the systematic development of a scale. Journal of Organizational Change Management,, 22(6), 635-649.

Kantabutra, S. (2007). Vision effects in Thai retail stores: practical implications. International Journal of Retail \& Distribution Management, 36(4), 323-342.

Kenny, J. (2006). Strategy and the learning organization: a maturity model for the formation of strategy. The Learning Organization, 13(4), 353-368.

Lee, S. Y., Weiner, B. J., Harrison, M. I., \& Belden, C. M. (2013). Organizational Transformation A Systematic Review of Empirical Research in Health Care and Other Industries. Medical Care Research and Review, 70(2), 115-142.

Levin, I. M. (2000). Vision Revisited Telling the Story of the Future. The Journal of Applied Behavioral Science, 36(1), 91-107.

Lundvall, B. A. (2009). Innovation as an interactive process: user-producer interaction to the national system of innovation. African journal of science, technology, innovation and development, 1(2), 10-34.

McKinsey \& Company. (2008, July). Creating Organizational Transformation. The McKinsey Quarterly, pp. 1-7.

Michela, P., Carlotta, M. C., \& Andrea, C. (2012). Organizational Change: Business Process Reengineering Or Outsourcing? Annals of Faculty of Economic, 1(2), 277-287.

Mintzberg, H., \& Westley, F. (1992). Cycles of organizational change. Strategic Management Journal, 13(S2), 39-59.

Montagna, J. M. (2005). A framework for the assessment and analysis of electronic government proposals. Electronic Commerce Research and Applications(4), 204-219.

Nadler, D. A., \& Tushman, M. L. (1989). Organizational frame bending: Principles for managing reorientation. The Academy of Management Executive, 3(3), 194-204.

Nonaka, I., \& Takeuchi, H. (1995). The knowledge-creating company: How Japanese companies create the dynamics of innovation. London: Oxford university press.

O'Connell, D., Hickerson, K., \& Pilluta, A. (2011). Organizational Visioning: An Integrated Review. Group and Organization Management, 36, 103-125.

Orlikowski, W. J. (1996). Improvising organizational transformation over time: A situated change perspective. Information systems research, 7(1), 63-92.

Pettigrew, A. M. (1987). Context and action in the transformation of the firm. Journal of management studies, 24(6), 649-670.

Porter, M. E. (1998). Clusters and the new economics of competition. Boston: Harvard Business Review, 76(6), pp. 77-90.

Sterling, S. (2010-11). Transformative Learning and Sustainability: sketching the conceptual ground. Learning and Teaching in Higher Education(5), 17-33.

Teece, D. J., Pisano, G., \& Shuen, A. (1997). Dynamic capabilities and strategic management. Strategic management journal, 18(7), 509-533. 
Van de Ven, A. H., \& Poole, M. S. (2005). Alternative approaches for studying organizational change. Organization studies, 26(9), 1377-1404.

Weick, K., \& Quinn, R. (1999). Organizational Change and Development. Annual Review Psychology, 50, 361-86.

West, D. M. (2004). E-government and the Transformation of Service Delivery and Citizen Attitudes. Public Administration Review, 64(1), 15-27.

Westley, F., \& Mintzberg, H. (1989). Visionary leadership and strategic management. Strategic Management Journal, 10, 17-32. 